SAINS TANAH - Journal of Soil Science and Agroclimatology

Journal homepage: http://jurnal.uns.ac.id/tanah

\title{
Characteristics of Ultisols derived from basaltic andesite materials and their association with old volcanic landforms in Indonesia
}

\author{
Setiyo Purwanto*, Rachmat Abdul Gani ${ }^{1}$ Erna Suryani $^{1}$ \\ Indonesian Center for Agricultural Land Resource Research and Development - ICALRRD
}

\begin{tabular}{|c|c|}
\hline ARTICLE INFO & ABSTRACT \\
\hline Keywords: & The common problem with Ultisols is their low $\mathrm{pH}$ and soil fertility, with liming and \\
\hline Pedon & fertilization being common solutions to overcome this problem; however, studies on \\
\hline Minerals & Ultisol soil parent materials are still rare. This study aimed to examine the characteristics \\
\hline Parent material & of Ultisols derived from andesite and basaltic andesite parent materials. In 2016-2017, five \\
\hline Weathering & Ultisol pedons (P8, P9, P10, P11, and P15) were sampled from basaltic andesites and other \\
\hline Soil fertility & $\begin{array}{l}\text { associations. The five pedons consisted of } 19 \text { soil samples. The chemical and mineralogical } \\
\text { properties of the soils were analyzed. It was found that the color of the basaltic andesite }\end{array}$ \\
\hline Article history & Ultisols varied from hue of 2.5 YR to $10 \mathrm{YR}$, with value of $3-5$ and chroma of $2-8$. The \\
\hline Submitted: 2019-12-23 & Ultisols derived from andesite/diorite (P8) were dominated by rock fragments ( $52-77 \%)$, \\
\hline Accepted: 2020-12-11 & $\begin{array}{l}\text { while those derived from andesitic breccia (P9) were dominated by opaques }(62-67 \%) \text {, } \\
\text { those from basaltic andesite tuff/lava by weathering minerals }(44-52 \%) \text { and hydragilite }\end{array}$ \\
\hline * Corresponding Authors & (28-34\%), those from basaltic andesite (P11) by quartz (48\%) and (P15) by opaques (79- \\
\hline $\begin{array}{l}\text { Email address: } \\
\text { teteptio@gmail.com }\end{array}$ & $\begin{array}{l}89 \%) \text {. The mineral reserves varied from very low }(0-4 \%) \text { in pedons } \mathrm{P} 8, \mathrm{P} 9, \mathrm{P} 11 \text {, and } \mathrm{P} 15 \text { to } \\
\text { very high }(>40 \%) \text { in pedon P10. The results of this study are expected to be used as a guide } \\
\text { for future agricultural development on Ultisols. }\end{array}$ \\
\hline
\end{tabular}

How to Cite: Purwanto, S., Gani, R. A., and Suryani, E. (2020). Characteristics of Ultisols derived from basaltic andesite materials and their association with old volcanic landforms in Indonesia. Sains Tanah Journal of Soil Science and Agroclimatology, 17(2): 135-143 (doi: 10.20961/stjssa.v17i2.38301)

\section{Introduction}

Ultisols are a type of soil with an advanced level of development, characterized by the presence of Argillic or Candic horizons, an increase in soil clay content (illuviation) in the soil pedon, and low base saturation (BS $<35 \%$ ). This type of soil has a fairly wide distribution in Indonesia. The Center for Soil and Agro-climate Research (Pusat Penelitian Tanah dan Agroklimat, 2000) found that the area in Indonesia covered by Ultisols was up to $45.8 \mathrm{Mha}$, or $24 \%$ of the total area of Indonesia. According to Hardjowigeno (1993), Ultisols cover the largest part of dry land in Indonesia.

The assessment of the Ultisols in this study followed the rules of the Soil Survey Staff (2014b) for classification purposes. These soils characteristically have ochric epipedon, with accumulations of clay (argillic), a reddish soil color in the lower layer, visible washing of color, and low BS. Based on the Indonesian National Soil Classification (Subardja et al., 2016), a Ultisol is defined as a soil that has an argillic $B$ horizon, or is candic, has a BS of $<50 \%$ (NH4OAC), at least in some parts of the $B$ horizon, at a depth of $125 \mathrm{~cm}$ from the surface, and does not have an albic horizon directly adjacent to the argillic horizon. Such Ultisols are known as podzols.

Ultisols are often referred to as being low fertility soils, due to their low cation exchange capacity (CEC), BS, and soil $\mathrm{pH}$. In addition, Widiatmaka et al. (2016) stated that Ultisols are old soils, with high acidity and Al exchangeability. A general solution for the management of Ultisols for agricultural purposes is the concept of balanced fertilization and liming. This is done to increase the soil $\mathrm{pH}$ and provide additional nutrients for the crops. According to Prasetyo \& Suriadikarta (2006), this particular solution has limitations because it does not consider certain aspects of the soilforming materials in the field. Every soil inherits the nature of its constituent parent material, and so considering these aspects is obviously important in the technical management of agricultural land. The purpose of this study was to determine the characteristics of Ultisols derived from andesite and basaltic andesite. The findings of the study are expected to be used as recommendations for the management of Ultisols in agricultural development. 
Table 1. Pedons, landforms, parent materials, and locations of Ultisol soil sampling

\begin{tabular}{clll}
\hline Pedon & \multicolumn{1}{c}{ Landform } & \multicolumn{1}{c}{ Parent Material } & \multicolumn{1}{c}{ Location } \\
\hline P8 & Volcanic intrusions & Andesite and diorite & Sukatani district, Purwakarta, West Java \\
P9 & Volcanic hills & Andesitic breccia & Gunung Halu district, West Bandung, West Java \\
P10 & Old volcanic hills & Basaltic andesite lava and tuff & Tondong Tallasa district, Pangkep, South Sulawesi \\
P11 & Old volcanic hills & Basaltic andesite & Lengkiti district, Ogan Komering Ulu, South Sumatra \\
P15 & Old volcanic mountains & Basaltic andesite & Banjarharjo district, Brebes, Central Java \\
\hline
\end{tabular}

Andesites are igneous rocks with an intermediate composition. They are light to dark in color, with low $\mathrm{SiO}_{3}$ content and significant quantities of $\mathrm{Fe}$ and $\mathrm{Mg}$. The process of soil formation from such rocks produces a soil texture from clay loam to clay. According to Chinchilla et al. (2011), basaltic andesite rocks contain the minerals plagioclase, olivine, pyroxene, and feldspar. All these minerals are a source of reserve nutrients which can be utilized by plants, with plagioclases being rich in $\mathrm{Ca}$ and $\mathrm{Na}$ and alkaline feldspars (one of the subgroups of feldspars) being rich in $\mathrm{K}$. In general, Ultisols developed from volcanic rocks have a relatively better performance, with respect to being used as agricultural soils, than those from sedimentary materials.

Advanced research on the formation of Ultisols deriving from various types of parent material is of great interest. Ultisols can be formed from a variety of parent materials, specifically igneous (e.g., andesite, basalt, and basaltic andesite) and sedimentary (claystones and sandstones). In Indonesia, Ultisols have formed on acidic tuffs in Lampung (Buurman and Dai, 1976), granodiorite in West Kalimantan (Buurman \& Soebagjo, 1980; Suharta, 1986), metamorphics and sediments in Southeast Sulawesi (Dai \& Soedewo, 1980), claystones and sandstones in Riau (Suhardjo, 1989), sediments in East Kalimantan (Sulaeman, 2001), and andesitic volcanic (Prasetyo et al., 2005) and sediments in Aceh (Andalusia \& Arabia, 2016). Studies on Ultisols derived from basaltic andesites and their associated rock types, however, are still rare in Indonesia. Since soil formation is influenced by the interaction of five factors, according to Jenny (1941), research on Ultisols that considers these factors in terms of their parent material in Indonesia (i.e., basaltic andesite) will fill this gap in our scientific knowledge. The purpose of this study was therefore to determine the characteristics of Ultisols derived from andesite and basaltic andesite from various locations in Indonesia.

\section{Materials and Method}

Soil samples were taken during soil mapping survey activities in Indonesia in 2016 and 2017. The locations of the pedon landforms and parent materials sampled from five districts are presented in Table 1 . Hundreds of pedons were identified. Five Ultisol pedons from five districts in four provinces (Central Java, West Java, South Sumatra, and South Sulawesi), derived from andesite and its associations, were selected for further analysis.

In the laboratory of the Soil Research Center Bogor, West Java, 19 soil samples were extracted from the five pedons ( $P 8$, P9, P10, P11, and P15). From these, data on the soil mineralogy and chemistry were obtained. Tests on the physical and chemical properties included texture, organic matter content, $\mathrm{pH}$ (in $\mathrm{H}_{2} \mathrm{O}$ and $\mathrm{KCl}$ ), potential $\mathrm{P}$ and $\mathrm{K}(25 \% 1$ $\mathrm{N} \mathrm{HCl}$ ), available $\mathrm{P}$ (Olsen), interchangeable cation capacity, and exchangeable cations (1 N NH $\mathrm{NOAc}_{4} \mathrm{pH}$ 7.0). The analyses followed the methods of Kellog (Soil Survey Staff, 2014a) and the testing protocols of the Soil Research Center (BPT, 2009).

Table 2. Pedon depths, soil colors, textures, and classification of Ultisols

\begin{tabular}{|c|c|c|c|c|c|}
\hline Pedon & $\begin{array}{l}\text { Horizon } \\
\text { Symbol }\end{array}$ & Depth (cm) & Soil Color & Texture & Soil Taxonomy (Soil Survey Staff USDA, 2014) \\
\hline \multirow{5}{*}{ P8 } & $A p$ & $0-21$ & 7.5 YR 4/6 & Clay & \multirow{5}{*}{$\begin{array}{l}\text { Typic Hapludults, very fine, kaolinitic, } \\
\text { isohyperthermic }\end{array}$} \\
\hline & Bt1 & $21-53$ & 7.5 YR 4/4 & Clay & \\
\hline & $\mathrm{Bt} 2$ & $53-94$ & 7.5 YR 5/6 & Clay & \\
\hline & $\mathrm{Bt} 3$ & $94-131$ & 10 YR 5/4 & Clay & \\
\hline & Bt4 & $131-150$ & 7.5 YR 5/6 & Clay & \\
\hline \multirow{4}{*}{ P9 } & $A p$ & $0-25$ & 5 YR 3/4 & Clay & \multirow{4}{*}{$\begin{array}{l}\text { Typic Hapludults, very fine, kaolinitic, } \\
\text { isohyperthermic }\end{array}$} \\
\hline & Bt1 & $25-55$ & 5 YR 4/4 & Clay & \\
\hline & $\mathrm{Bt} 2$ & $55-90$ & 2.5 YR $4 / 6$ & Clay & \\
\hline & $\mathrm{Bt} 3$ & $90-150$ & 2.5 YR 4/6 & Clay & \\
\hline \multirow{4}{*}{ P10 } & $A p$ & $0-15$ & 10 YR $3 / 3$ & Clay & \multirow{4}{*}{$\begin{array}{c}\text { Typic Hapludults, very fine, kaolinitic, } \\
\text { isohyperthermic }\end{array}$} \\
\hline & Bt1 & $15-42$ & 7.5 YR 4/4 & Clay & \\
\hline & Bt2 & $42-83$ & 7.5 YR 4/6 & Clay & \\
\hline & $\mathrm{Bt} 3$ & $83-130$ & 10 YR 4/4 & Clay & \\
\hline \multirow{2}{*}{ P11 } & $A p$ & $0-12$ & 7.5 YR $3 / 3$ & Clay & \multirow{2}{*}{$\begin{array}{l}\text { Lithic Hapludults, very fine, kaolinitic, } \\
\text { isohyperthermic }\end{array}$} \\
\hline & Bt1 & $12-37$ & 7.5 YR 3/4 & Clay & \\
\hline \multirow{4}{*}{ P15 } & $A p$ & $0-15$ & 5 YR 3/4 & Clay & \multirow{4}{*}{$\begin{array}{l}\text { Typic Hapludults, very fine, kaolinitic, } \\
\text { isohyperthermic }\end{array}$} \\
\hline & Bt1 & $15-42$ & 5 YR 4/4 & Clay & \\
\hline & $\mathrm{Bt} 2$ & $42-83$ & 5 YR 4/6 & Clay & \\
\hline & $\mathrm{Bt} 3$ & $83-130$ & 5 YR 4/6 & Clay & \\
\hline
\end{tabular}


The mineralogical analysis included an examination of the total sand fraction, using a polarizing-light microscope and an inline counting method (Carter \& Gregorich, 2007) and of the clay fraction by $\mathrm{X}$-ray diffraction using a combination of several methods, including concentrating the clay fraction according to Stokes' law and coating a ceramic surface with it (Klute \& Page, 1986).

\section{Results}

\subsection{Soil physical and Morphological properties}

Pedons P8 to P15 (Table 1) were taken from four different provinces (West Java, Central Java, South Sulawesi, and South Sumatra), with elevations ranging from 160 to $1045 \mathrm{~m}$ above sea level. The soils were classified as Ultisols based on the US Department of Agriculture (USDA) taxonomic system (Soil Survey Staff, 2014b). The soil parent materials were basaltic andesite, andesite/diorite, andesitic breccia, lava, and basaltic andesite tuff, based on the Indonesian soil map atlas (Balai Besar Penelitian dan Pengembangan Sumberdaya Pertanian, 2019).

Ultisols from basaltic andesite (and its associations) have a deep solum $(>120 \mathrm{~cm}$ ) and a clay texture, with the soil color varying, hue from 2.5 YR to $10 \mathrm{YR}$, with value of 3-5 and chroma of 3-6 (Table 2). The color of the soil in the study area was influenced by the amount of organic matter content (with black coloration coming from the composition of the organic material), rainfall, and the degree of weathering of the soil parent material.

\subsection{Sand mineral properties}

The 19 samples from the five pedons were analyzed for their primary mineral (sand) composition, using a polarizinglight microscope with an inline counting technique. The results are given in Table 3, where the soils were dominated by opaque minerals, zircon, quartz weathering minerals, rock fragments, and hypersthene.

Rock fragments are complex mineral entities that comprise more than one type of mineral, in which the mineral types cannot be precisely determined through direct observation. Rock fragments were found in all the pedons (P8-P15), in sporadic amounts up to $70 \%$. The highest amount was found in P8, and these comprised andesite/diorite. Weathering minerals were also found in all the pedons (P8$\mathrm{P} 15)$, in amounts from 2 to $52 \%$. The highest amount was found in P10, in basaltic andesite tuff/lava material.

\subsection{Soil chemical properties}

Several chemical properties were determined in the laboratory, including the $\mathrm{CEC}, \mathrm{BS}, \mathrm{C} / \mathrm{N}$ ratio, $\mathrm{P}, \mathrm{K} 2 \mathrm{O}, \mathrm{Ca}, \mathrm{Mg}, \mathrm{K}$, and $\mathrm{Na}$. The status of the organic matter content was identified through the analysis of $\mathrm{C}$ and $\mathrm{N}$ (Table 4). The organic $\mathrm{C}$ content in the basaltic andesite pedons (P11 and $\mathrm{P} 15)$ ranged from very low $(<1 \%)$ to low $(1-2 \%)$, while in the basaltic andesite tuff/lava (P10), it ranged from very low to moderate (2-3\%), with the upper layer (topsoil) having higher values. The pedon formed from andesitic breccia (P9) had an organic $C$ content ranging from very low to low, with the pedon from andesite/diorite (P8) having very low values.
Table 4 shows the available $P$ content was identified using Olsen's analysis (Soil Survey Staff USDA, 2014a). The basaltic andesite (P11 and P15) pedons had very low $(<5 \%)$ to low $(5-$ $10 \%) P$ values, while the basaltic andesite tuff/lava (P10) had $P$ values ranging from low (5-10\%) to moderate (11-15\%). The pedon developed from andesitic breccia (P9) had very low to low $P$ values, and the andesite/diorite (P8) pedon had moderate values.

Table 5 show that the Ultisols developed from basaltic andesite (P11 and P15) had CEC values ranging from low (5$16 \%)$ to moderate (17-24\%), with the basaltic andesite tuff/lava (P10) having values in the high (25-40\%) to very high (> 40\%) range, and the andesite/diorite (P8) and andesitic breccia (P9) pedons having moderate (17-24\%) values. There was a close relationship between the mineral reserves and CEC values, with P10 having high (20-40\%) to very high (> $40 \%)$ mineral reserves, these values corresponding to high to very high CEC values.

The BSs of the pedons derived from basaltic andesite (P11 and $\mathrm{P} 15)$ had values varying from very low $(<20 \%)$ to low $(20$ $40 \%)$, while the pedons derived from basaltic andesite tuff/lava (P10), andesite/diorite (P8) and andesitic breccia (P9) had low values. Combined, these findings indicate that Ultisols developed on basaltic andesite and its associations have low BS values.

\subsection{Resistant (advanced weathering) minerals}

The soils were dominated by resistant minerals, including opaques, quartz, and zircon. Opaques ranged from $8-89 \%$ in the basaltic andesite samples P11 and P15, 3-5\% in the basaltic andesite tuff/lava sample (P10), 10-35\% in the andesite/diorite sample (P8), and 62-67\% in the andesitic breccia sample (P9). A sporadic range (SR) is when microscopic observation of minerals was found, but when the line counting process minerals were not found. Quartz (clear and cloudy types) was found in P11 and P15, with an SR of 58\%, and $2 \%$ in P8 (andesite/diorite), and 12-20\% in P9 (andesitic breccia). Zircon was found in P11 and P9, with an SR of $1 \%$.

\subsection{Early weathering minerals}

The soils were dominated by resistant minerals, including opaques, quartz, and zircon. Opaques ranged from $8-89 \%$ in the basaltic andesite samples $\mathrm{P} 11$ and $\mathrm{P} 15,3-5 \%$ in the basaltic andesite tuff/lava sample (P10), 10-35\% in the andesite/diorite sample (P8), and $62-67 \%$ in the andesitic breccia sample (P9). A sporadic range (SR) is when microscopic observation of minerals was found, but when the line counting process minerals were not found. Quartz (clear and cloudy types) was found in P11 and P15, with an SR of $58 \%$, and $2 \%$ in P8 (andesite/diorite), and $12-20 \%$ in P9 (andesitic breccia). Zircon was found in P11 and P9, with an SR of $1 \%$.

The interchangeable cations analyzed in the laboratory were $\mathrm{Ca}, \mathrm{Mg}, \mathrm{K}$, and $\mathrm{Na}$ (Table 5). The pedons developed on basaltic andesite (P11 and P15) had Ca cation exchange values ranging from very low $(<2 \mathrm{cmol} \mathrm{kg}-1)$ to low $(2-5 \mathrm{cmol} \mathrm{kg}-1)$, with those from basaltic andesite tuff/lava (P10), andesitic breccia (P9) and andesite/diorite (P8) having a low rate of Ca cation exchange. 
Table 3. Composition of primary minerals (sand fraction) in some Ultisols pedons

\begin{tabular}{|c|c|c|c|c|c|c|c|c|c|c|c|c|c|c|c|c|c|c|c|c|c|c|c|c|c|c|c|}
\hline \multirow[t]{2}{*}{ Pedon } & \multirow{2}{*}{$\begin{array}{l}\text { Depth } \\
(\mathrm{cm})\end{array}$} & \multicolumn{24}{|c|}{ Type of Mineral (\%) } & \multirow[t]{2}{*}{$\begin{array}{l}\text { Mineral Reserves } \\
\text { (MR) (\%) }\end{array}$} & \multirow{2}{*}{$\begin{array}{c}\text { MR } \\
\text { Class }\end{array}$} \\
\hline & & Op & $\mathbf{Z i}$ & $\mathrm{Dq}$ & $\mathrm{Cq}$ & Ic & Li & SiO & Ze & Hd & $\mathrm{Wm}$ & Rf & Gv & Lb & $\mathrm{Bi}$ & Or & Sa & $\mathrm{Bt}$ & Gh & $\mathrm{Bh}$ & $\mathrm{Au}$ & $\mathrm{Hi}$ & Ga & Ep & $\mathrm{Tu}$ & & \\
\hline \multirow{5}{*}{ P8 } & $0-21$ & 10 & - & 2 & $s p$ & 5 & 3 & - & - & - & 5 & 70 & - & 1 & 1 & - & 1 & - & - & - & 1 & 1 & - & - & - & 5 & $\mathrm{~L}$ \\
\hline & $21-53$ & 14 & - & 1 & sp & 3 & 2 & - & - & - & 3 & 77 & - & sp & sp & - & sp & - & - & - & sp & sp & - & - & - & 0 & VL \\
\hline & $53-94$ & 17 & - & $\mathrm{sp}$ & - & 3 & 1 & - & - & - & 6 & 73 & - & sp & - & - & - & - & - & - & - & - & - & - & - & 0 & VL \\
\hline & $94-131$ & 28 & - & sp & - & 4 & 2 & - & - & - & 4 & 62 & - & - & - & - & $\mathrm{sp}$ & - & - & - & - & - & - & - & - & 0 & VL \\
\hline & $131-150$ & 35 & - & 2 & - & 6 & 3 & - & - & - & 2 & 52 & - & - & - & - & - & - & - & - & - & $\mathrm{sp}$ & - & - & - & 0 & $\mathrm{VL}$ \\
\hline \multirow{4}{*}{ P9 } & $0-25$ & 65 & 1 & 4 & 8 & - & - & - & $\mathrm{sp}$ & - & 5 & 3 & 2 & 1 & - & - & - & - & 4 & - & 2 & 5 & - & - & - & 14 & $M$ \\
\hline & $25-55$ & 67 & $s p$ & 5 & 7 & $s p$ & - & $s p$ & - & $s p$ & 7 & 5 & 3 & $s p$ & - & - & - & - & 2 & - & 1 & 3 & - & - & - & 9 & $\mathrm{~L}$ \\
\hline & $55-90$ & 63 & 1 & 7 & 9 & sp & - & - & $\mathrm{sp}$ & sp & 8 & 6 & 2 & - & - & - & sp & - & 1 & - & 1 & 2 & $\mathrm{sp}$ & - & - & 6 & $\mathrm{~L}$ \\
\hline & $90-150$ & 62 & $\mathrm{sp}$ & 8 & 12 & - & - & - & - & - & 6 & 8 & 1 & - & - & - & - & - & 2 & - & $\mathrm{sp}$ & 1 & - & - & - & 4 & $\mathrm{VL}$ \\
\hline \multirow{4}{*}{ P10 } & $0-15$ & 3 & - & $\mathrm{sp}$ & - & $\mathrm{sp}$ & 4 & - & $\mathrm{sp}$ & - & 44 & 5 & - & 8 & - & - & - & - & - & - & 2 & 34 & - & $s p$ & - & 44 & $\mathrm{VH}$ \\
\hline & $15-42$ & 4 & - & sp & sp & sp & 3 & - & $\mathrm{sp}$ & - & 47 & 6 & - & 6 & - & - & - & - & - & - & 3 & 31 & - & sp & - & 40 & $\mathrm{H}$ \\
\hline & $42-83$ & 5 & - & - & - & sp & 1 & - & - & - & 52 & 6 & - & 5 & - & - & - & - & - & - & 1 & 30 & - & - & - & 36 & $\mathrm{H}$ \\
\hline & $83-130$ & 4 & - & $\mathrm{sp}$ & - & 1 & 2 & - & - & - & 48 & 7 & - & 8 & - & - & - & - & - & - & 2 & 28 & - & $\mathrm{sp}$ & - & 38 & $\mathrm{H}$ \\
\hline \multirow{2}{*}{ P11 } & $0-12$ & 8 & 1 & 27 & 31 & $\mathrm{sp}$ & - & - & - & - & 9 & 21 & 1 & $\mathrm{sp}$ & - & 1 & 1 & - & - & - & $s p$ & $s p$ & - & - & - & 3 & $\mathrm{VL}$ \\
\hline & $12-37$ & 13 & $\mathrm{sp}$ & 22 & 25 & 1 & - & - & - & - & 8 & 27 & $\mathrm{sp}$ & sp & - & $\mathrm{sp}$ & 1 & - & - & - & 1 & 2 & - & - & $\mathrm{sp}$ & 4 & $\mathrm{VL}$ \\
\hline \multirow{4}{*}{ P15 } & $0-13$ & 79 & - & $\mathrm{sp}$ & - & - & - & - & - & - & 6 & 1 & sp & 2 & - & - & - & $\mathrm{sp}$ & 3 & $s p$ & 4 & 5 & - & - & - & 14 & $M$ \\
\hline & $13-45$ & 86 & - & - & - & $\mathrm{sp}$ & - & - & - & - & 5 & 1 & - & 1 & - & - & - & - & 2 & - & 3 & 2 & - & - & - & 8 & $\mathrm{~L}$ \\
\hline & $45-73$ & 89 & - & - & $\mathrm{sp}$ & - & - & - & - & - & 7 & $s p$ & - & $s p$ & - & - & - & $\mathrm{sp}$ & 1 & - & 2 & 1 & - & - & - & 4 & VL \\
\hline & $73-130$ & 87 & - & - & - & - & - & - & - & - & 8 & 1 & $\mathrm{sp}$ & 1 & - & - & - & - & 1 & - & 1 & 1 & - & - & - & 4 & VL \\
\hline
\end{tabular}

Remarks: Op—opaque, Zi-zircon, Dq—cloud quartz, Cq-clear quartz, Ic-iron concretion, Li-limonite, SiO-organic SiO2, Ze-zeolite, Hd-hydragilite, Wm-weathering mineral, Rfrock fragment, $\mathrm{Vg}$ — volcanic glass, Al—albite, Ol—oligoclase, An—andesine, Lb—labradorite, Bi-bytownite, At—anorthite, Or-orthoclase, Sa-sanidine, Mu—muscovite, Btbiotite, Gh—green hornblende, Bh—brown hornblende, Au-augite, Hi-hypersthene, Ga—garnet, Ep—epidote, Tu—tourmaline, Ad-andalusite, Sm-sillimanite, Es-enstatite, sp-sporadic, VL—very low, VH—very high, L-low, H-high, M-moderate 
Table 4. Texture, organic $\mathrm{C}, \mathrm{pH}$, and $\mathrm{P}$ content $\mathrm{pf}$ five Ultisosl pedons

\begin{tabular}{|c|c|c|c|c|c|c|c|c|c|c|c|}
\hline \multirow{3}{*}{ Pedon } & \multirow{3}{*}{ Depth $(\mathrm{cm})$} & \multicolumn{3}{|c|}{ Texture } & \multirow{2}{*}{$\begin{array}{l}\mathrm{pH} \\
\mathrm{H}_{2} \mathrm{O}\end{array}$} & \multirow{2}{*}{$\begin{array}{l}\text { Carbon } \\
\text { Organic }\end{array}$} & \multicolumn{2}{|c|}{$\mathrm{HCl} 25 \%$} & \multirow{2}{*}{$\begin{array}{l}\text { Olsen } \\
\mathrm{P}_{2} \mathrm{O}_{5}\end{array}$} & \multirow{2}{*}{$\begin{array}{l}\text { Bray } 1 \\
\mathrm{P}_{2} \mathrm{O}_{5}\end{array}$} & \multirow{2}{*}{$\begin{array}{c}\text { Morgan } \\
\mathbf{K}_{2} \mathrm{O}\end{array}$} \\
\hline & & Sand & Silt & Clay & & & $\mathbf{P}_{2} \mathbf{O}_{5}$ & $\mathrm{~K}_{2} \mathrm{O}$ & & & \\
\hline & & \multicolumn{3}{|c|}{--------- \% -------- } & & $\%$ & \multicolumn{2}{|c|}{$--\mathrm{mg} / 100 \mathrm{~g} \mathrm{--}$} & ppm & ppm & ppm \\
\hline \multirow{5}{*}{ P8 } & $0-21$ & 14.00 & 23.00 & 63.00 & 5.20 & 0.84 & 62.69 & 22.70 & 8.73 & - & - \\
\hline & $21-53$ & 8.00 & 20.00 & 72.00 & 5.10 & 0.46 & 36.24 & 33.87 & 5.87 & - & - \\
\hline & $53-94$ & 7.00 & 25.00 & 68.00 & 4.99 & 0.46 & 45.94 & 28.48 & 3.98 & - & - \\
\hline & $94-131$ & 8.00 & 29.00 & 63.00 & 4.98 & 0.26 & 50.12 & 26.57 & 9.69 & - & - \\
\hline & $131-150$ & 8.00 & 24.00 & 68.00 & 5.10 & 0.27 & 50.00 & 35.69 & 4.44 & - & - \\
\hline \multirow{4}{*}{ P9 } & $0-25$ & 4.00 & 13.00 & 83.00 & 4.36 & 1.84 & 39.69 & 15.00 & - & 0.91 & - \\
\hline & $25-55$ & 3.00 & 2.00 & 95.00 & 4.84 & 1.04 & 50.38 & 7.00 & - & 1.23 & - \\
\hline & $55-90$ & 3.00 & 3.00 & 94.00 & 4.92 & 0.76 & 41.83 & 3.00 & - & 1.00 & - \\
\hline & $90-150$ & 4.00 & 3.00 & 93.00 & 4.94 & 0.60 & 44.24 & 3.00 & - & 1.00 & - \\
\hline \multirow{4}{*}{ P10 } & $0-15$ & 28.00 & 25.00 & 47.00 & 5.06 & 2.96 & 113.67 & 26.20 & 11.56 & - & - \\
\hline & $15-42$ & 26.00 & 18.00 & 56.00 & 4.99 & 0.78 & 102.93 & 15.00 & 9.64 & - & - \\
\hline & $42-83$ & 33.00 & 12.00 & 55.00 & 5.10 & 0.49 & 74.51 & 10.00 & 8.54 & - & - \\
\hline & $83-130$ & 33.00 & 16.00 & 51.00 & 4.97 & 0.45 & 79.96 & 12.00 & 8.79 & - & - \\
\hline \multirow{2}{*}{ P11 } & $0-12$ & 27.00 & 27.00 & 46.00 & 4.50 & 1.43 & 31.00 & 6.00 & - & 3.40 & 56.00 \\
\hline & $12-37$ & 23.00 & 27.00 & 50.00 & 4.50 & 2.60 & 37.00 & 9.00 & - & 7.90 & 87.00 \\
\hline \multirow{4}{*}{ P15 } & $0-15$ & 15.00 & 36.00 & 49.00 & 5.36 & 2.97 & 30.40 & 17.00 & 4.68 & - & - \\
\hline & $15-42$ & 14.00 & 30.00 & 56.00 & 5.17 & 1.49 & 28.52 & 10.00 & 3.79 & - & - \\
\hline & $42-83$ & 14.00 & 36.00 & 50.00 & 5.00 & 0.52 & 25.26 & 4.00 & 5.20 & - & - \\
\hline & $83-130$ & 21.00 & 35.00 & 44.00 & 4.98 & 0.54 & 25.97 & 4.00 & 3.20 & - & - \\
\hline
\end{tabular}

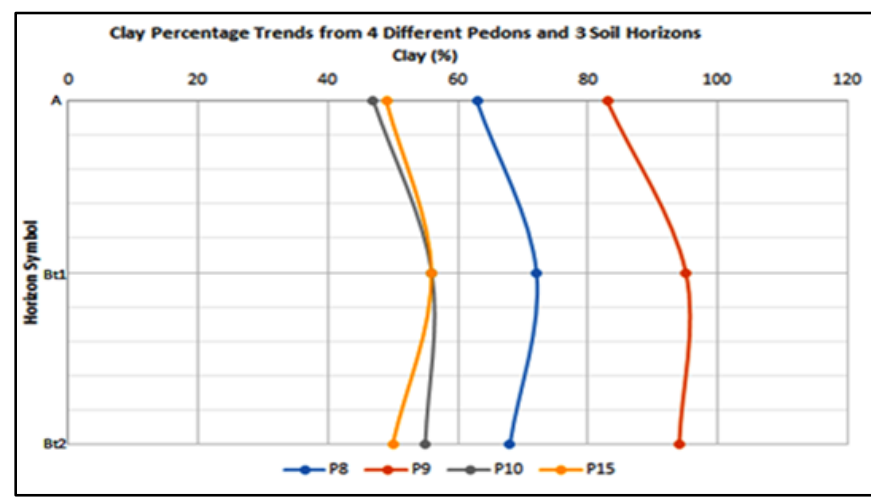

Figure 1. Clay content in four pedons (P8, P9, P10, and P15) in the $A, B t 1$, and Bt2 horizons

For $\mathrm{Mg}$, the cation exchange values in each pedon were low $\left(0.4-1 \mathrm{cmol} \mathrm{kg}^{-1}\right)$ to high $\left(2.1-8.0 \mathrm{cmol} \mathrm{kg}^{-1}\right)$ for basaltic andesite (P11 and P15), high for basaltic andesite tuff/lava (P10), moderate $\left(1.1-2.0 \mathrm{cmol} \mathrm{kg}^{-1}\right)$ to high $\left(2.1-8.0 \mathrm{cmol} \mathrm{kg}^{-1}\right)$ for andesitic breccia (P9), and moderate for andesite/diorite (P8). In general, three pedons had high $\mathrm{Mg}$ values that could be exchanged. This is related to the sand mineral content of hypersthene and hornblende, which have Mg-based chemical compositions.

The exchangeable $K$ cation values were very low $0.1 \mathrm{cmol}$ $\mathrm{kg}^{-1}$ ) to low $(0.1-0.3 \mathrm{cmol} \mathrm{kg}$ ) for the pedons derived from basaltic andesite (P11 and P15), low (0.1-0.3 $\mathrm{cmol} \mathrm{kg}^{-1}$ ) to moderate $(0.4-0.5 \mathrm{cmol} \mathrm{kg}-1)$ for the pedon developed on basaltic andesite tuff/lava (P10), very low to low for andesitic breccia (P9), and low to moderate for andesite/diorite (P8). The $\mathrm{Na}$ exchangeable cation values were low $(0.1-0.3 \mathrm{cmol}$ $\left.\mathrm{kg}^{-1}\right)$ for P11 and P15, and very low $\left(<0.1 \mathrm{cmol} \mathrm{kg}^{-1}\right)$ for P8, P9 and P10.

\section{Discussion}

The Ultisols from the studied sites generally had a clay texture, which accords with the finding of Prasetyo \& Suriadikarta (2006), that Ultisols that develop from andesitic materials have a clay texture. In general, fine-textured (i.e., clay) soils have low percentages of micropores, so the infiltration of water to deeper horizons is inhibited, which leads to increased surface erosion (i.e., runoff). The soil colors derived from the basaltic andesite (and its associations) in the study area varied from 2.5 YR to $10 \mathrm{YR}$, with values of 3-5 and chroma of 3-6 (Table 2). Soil color is strongly influenced by organic matter content, rainfall, and the degree of weathering of the parent material, with black coloration deriving from the composition of the organic matter. A grayish-white color is contributed by quartz and some plagioclase feldspars, a brownish-red color represents the influence of Fe-rich (Fe oxide) minerals, such as goethite and hematite, with more intense browns generally indicating a higher goethite composition and more intense reds indicating more hematite (Allen; Hajek, 1989; Eswaran H and Sys, 1970; Schwertmann \& Taylor, 1989). According to Irmak et al. (2007), well-developed soils that derive from basalts often have an earthy red color as a result of high $\mathrm{Fe}_{2} \mathrm{O}_{3}$ content.

The five pedons have an ochric characteristic horizon (epipedon) in terms of soil color (value/chroma $>3 / 3$ ) and horizon depth $(<25 \mathrm{~cm}), \mathrm{P} 10$ and $\mathrm{P} 11$ pedons have $3 / 3$ matrix color, but the depth is less than $25 \mathrm{~cm}$, so it cannot be so it is not can be inserted into a mollic or umbric epipedon. The low horizon (endopedon) of the five pedons can be put into argillic, where there is an increase in clay (illuviation) in the Bt1 horizon (Figure 1). All these characteristics are in line with the USDA classification and the Indonesian National Soil 
Classification of ultisols determination (Soil Survey Staff, 2014b; Subardja et al., 2016). Both markers indicate that the soil is classified as ultisols (Table 2 ).

In general, the Ultisols in the study area had low carbon organic contents, available $\mathrm{P}, \mathrm{BS}$, and CEC values (BPT, 2009). According to Prasetyo \& Suriadikarta (2006), the low carbon organic $€$ content might be associated with a high degree of erosion (runoff) on the Ultisols, occurring because of the low percentage of pore space in the clay fractions. Wirjodihardjo \& Wisaksono (1953) stated that Ultisols have low available $P$ values, which can occur because $P$ is strongly bound to Fe from advanced weathering minerals. A low BS value is likely due to enhance mineral weathering, which makes many minerals rich in Fe. Low BS values are a Ultisol characteristic used by the Soil Taxonomy (Soil Survey Staff, 2014a) and National Soil Classifications (Subardja et al., 2016).

Resistant minerals are minerals that are very difficult to decay in nature because of the hardness of their crystalline constituents, particularly $\mathrm{SiO}_{2}$, and the process of their formation. In general, resistant minerals have a hardness of 6.5-7.5 on the Mohs scale (Tabor, 1954). The resistant minerals (opaques, quartz, and zircon) included in Table 3 were found in all the pedons. The amounts of resistant minerals were often quite high, ranging from $3-89 \%$ in the five pedons. The presence of these resistant minerals in the five study areas suggests that the soils were well developed, as articulated by Prasetyo (2009), who stated that welldeveloped soils, such as Ultisols, are dominated by quartz and opaque sand minerals. Resistant minerals generally cannot provide nutrient reserves for plant growth; however, Asano et al. (2018) found that quartz played a role in the formation of an organo-mineral complex, meaning that quartz can act as a binding agent and a protective agent for organic matter in the soil.

Early weathering minerals have low hardness values and so are easy to mechanically and chemically break down by weathering. According to Goldschmidt in Bowen (1922), minerals that form crystals rapidly at high temperatures $\left(1200^{\circ} \mathrm{C}\right)$ decompose relatively easily compared to minerals that form slowly at low temperatures $\left(600^{\circ} \mathrm{C}\right)$.

As explained by Hobart (2019), andesite is an igneous rock that occurs as lava flows associated with stratovolcanoes. It cools rapidly, producing small crystals. Andesite and diorite (the latter having similar composition, but with larger crystals, because it cools more slowly inside the earth) have a composition between that of basalt and granite rocks. This is because the parent material is the melted product of oceanic plates that are made of basalt. Andesites are rich in the minerals plagioclase feldspar, biotite, pyroxene, and amphibole. They usually do not contain quartz or olivine minerals, so the presence of quartz found in this study in the sand minerals (Table 3 ) can be attributed to the basaltic parent material.

According to several authors (Best, 1982; Jackson, 2012; Myron G, 2002; Szymanski \& Szkaradek, 2018; Winter, 2013), the primary sand mineral constituents of andesite are the plagioclase, pyroxene, and hornblende groups, with accessory minerals consisting of magnetite $\left(\mathrm{Fe}_{3} \mathrm{O}_{4}\right)$, biotite, apatite, ilmenite, and zircon. These were all found in the five pedons studied herein.

Table 5. Cations that could be exchanged, CEC and BS of five pedons

\begin{tabular}{|c|c|c|c|c|c|c|c|c|c|}
\hline \multirow{3}{*}{ Pedon } & \multirow{3}{*}{$\begin{array}{c}\text { Depth } \\
(\mathrm{cm})\end{array}$} & \multicolumn{4}{|c|}{ CEC } & \multirow{2}{*}{$\begin{array}{c}\text { Total } \\
\text { Soil } \\
\text { Cations }\end{array}$} & \multicolumn{2}{|c|}{ CEC } & \multirow[b]{2}{*}{ BS } \\
\hline & & $\mathrm{Ca}$ & $\mathrm{Mg}$ & $\mathbf{K}$ & $\mathrm{Na}$ & & Soil & Clay & \\
\hline & & \multicolumn{7}{|c|}{ 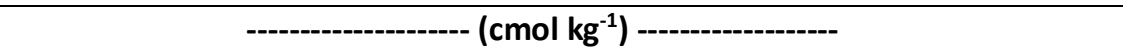 } & $(\%)$ \\
\hline \multirow{5}{*}{ P8 } & $0-21$ & 5.00 & 1.15 & 0.40 & 0.03 & 6.58 & 18.03 & 28.62 & 36.49 \\
\hline & $21-53$ & 3.54 & 1.58 & 0.55 & 0.03 & 5.70 & 19.37 & 26.90 & 29.43 \\
\hline & $53-94$ & 3.59 & 1.78 & 0.27 & 0.03 & 5.67 & 18.71 & 27.51 & 30.30 \\
\hline & $94-131$ & 4.79 & 1.24 & 0.23 & 0.05 & 6.31 & 17.80 & 28.25 & 35.45 \\
\hline & $131-150$ & 5.19 & 1.29 & 0.24 & 0.02 & 6.74 & 17.04 & 25.06 & 39.55 \\
\hline \multirow{4}{*}{ P9 } & $0-25$ & 2.91 & 1.76 & 0.29 & 0.04 & 5.00 & 20.07 & 24.18 & 24.91 \\
\hline & $25-55$ & 3.85 & 2.15 & 0.13 & 0.06 & 6.19 & 20.93 & 22.03 & 29.57 \\
\hline & $55-90$ & 3.18 & 2.61 & 0.05 & 0.20 & 6.04 & 19.31 & 20.54 & 31.28 \\
\hline & $90-150$ & 3.79 & 2.30 & 0.05 & 0.06 & 6.20 & 18.45 & 19.84 & 33.60 \\
\hline \multirow{4}{*}{ P10 } & $0-15$ & 5.89 & 3.97 & 0.54 & 0.05 & 10.45 & 42.21 & 89.81 & 24.76 \\
\hline & $15-42$ & 4.97 & 3.66 & 0.30 & 0.04 & 8.97 & 42.22 & 75.39 & 21.25 \\
\hline & $42-83$ & 2.27 & 5.88 & 0.20 & 0.04 & 8.39 & 41.39 & 75.25 & 20.27 \\
\hline & $83-130$ & 2.24 & 5.69 & 0.24 & 0.07 & 8.24 & 38.75 & 75.98 & 21.26 \\
\hline \multirow{2}{*}{ P11 } & $0-12$ & 1.44 & 0.63 & 0.11 & 0.14 & 2.32 & 16.87 & - & 14.00 \\
\hline & $12-37$ & 3.05 & 0.91 & 0.17 & 0.16 & 4.29 & 21.30 & - & 20.00 \\
\hline \multirow{4}{*}{ P15 } & $0-15$ & 4.03 & 2.73 & 0.34 & 0.23 & 7.33 & 18.50 & 37.76 & 39.62 \\
\hline & $15-42$ & 2.84 & 1.84 & 0.19 & 0.23 & 5.10 & 17.55 & 31.34 & 29.06 \\
\hline & $42-83$ & 1.93 & 3.02 & 0.07 & 0.14 & 5.16 & 16.97 & 33.94 & 30.41 \\
\hline & $83-130$ & 2.32 & 3.59 & 0.07 & 0.12 & 6.10 & 15.62 & 35.50 & 39.05 \\
\hline
\end{tabular}


Rock fragments found in the sand fraction of andesite represent strong evidence of physical and chemical weathering, while hornblende and augite minerals indicate the Fe oxidation process associated with weathering (Colman, 1982). Mineral weathering produces mineral waste from the weathering of the main constituent minerals, with the main mineral constituents decomposing in the soil produced. The presence of weathered minerals is often used to identify Ultisols, in addition to other types of minerals, such as magnetite (Fe concretions and limonite). This also explains why Ultisols are often characterized by the presence of large amounts of magnetite minerals (Ninuk, 1999).

Alkaline feldspar minerals sanidine and orthoclase were found in the study area. Sanidine (1\%) was found in P11 (basaltic andesite), P8 (andesite/diorite) at an SR of 1\%, and P9 (andesitic breccia) in sporadic quantities. Orthoclase minerals were found in P11, with an SR of $1 \%$. Sanidine and orthoclase have a Mohs hardness of 6 , and so both minerals decay easily, becoming a source of elemental $\mathrm{K}$ for plant growth (Manning, 2010). $\mathrm{K}$ is one of the three most important elements needed by plants (Skinner, 1984), regulating 60 enzyme systems (CPHA, 2003).

The plagioclase feldspars found in the study area include labradorite and bytownite. Labradorite was found in P11 and P15 with an SR of $2 \%$, in P8 with an SR of $1 \%$, in P9 with an SR of $<1 \%$, and in P10 at $5-8 \%$. Labradorite is a source of $\mathrm{Ca}$ and $\mathrm{Na}$. Bytownite was found in P8 at an SR of $1 \%$. Bytownite, and other plagioclase feldspar minerals, are rich in $\mathrm{Ca}$ and $\mathrm{Na}$. According to Asio \& Jahn (2007), Ca and $\mathrm{Na}$ are common in basalts, often being used to determine their degree of weathering, with the rate of loss being $\mathrm{Ca}>\mathrm{K}>\mathrm{Na}>\mathrm{Mg}>\mathrm{Si}$.

Augite, hypersthene, and enstatite are included in the pyroxene group. Augite was found in P11 and P15 at an SR of $4 \%$, in P10 ranging from $1-3 \%$, in P8 at an SR of $1 \%$, and in P9 at an SR of $<2 \%$. Hypersthene was found in P11 and P15 at an SR of 5\%, in P10 from 28-34\%, in P8 at an SR of $1 \%$, and in P9 from $1-2 \%$. Hypersthene is generally rich in $\mathrm{Mg}$ and $\mathrm{Fe}$, so its presence in the soil can be used as a source of these elements for plant growth. The amphibole mineral sand fraction included both green and brown hornblende. Both have chemical compositions rich in $\mathrm{Fe}, \mathrm{Mg}, \mathrm{Ca}, \mathrm{Al}$, and $\mathrm{Si}$. Hornblende was found in P15 at an SR of 3\%, and in P9 at an $\mathrm{SR}$ of $1-4 \%$. Hornblende is rich in $\mathrm{Ca}, \mathrm{Na}, \mathrm{Mg}$, $\mathrm{Fe}$, and $\mathrm{Al}$, so its presence in large quantities in the soil will have a positive impact on plant growth.

Mineral reserves are those minerals that are available in the soil or stored in the sand fraction for later release by weathering processes and can be used to meet the nutritional needs of plants. The mineral reserves in the soil can be calculated by adding up the types of minerals that can decay. According to Stanley et al. (2013), the type of sand mineral can be used as a predictor of nutrient reserves in the soil. The results showed that the pedons made from basaltic andesite (P11 and P15) had mineral reserves ranging from 3-14\%, this range being classed as very low to moderate. The mineral reserves in P11, originating from the Brebes Regency region, were relatively higher than in P15, from the Ogan Komering Ulu district, although both were present in low amounts and an external source of nutrient supply would still be needed for plant growth.

Pedon P10, originating in Pangkep Regency, South Sulawesi, had mineral reserves ranging from $36-44 \%$, and thus in the high to very high classes. This pedon is quite able to supply minerals for plant growth. According to Fatai et al. (2017) and Kolay (2007), basaltic material can be compared with ameliorants, such as the liming process, as it contains ferromagnetic minerals that easily release their elements into the soil. In addition, basalt can increase soil $\mathrm{pH}$. The pedon derived from andesite/diorite (P8), from Purwakarta Regency, West Java, had 5\% mineral reserves in the first layer (A), classed as low. This pedon therefore definitely requires an external supply of nutrients if it is to be used for agricultural cultivation. The pedon derived from andesitic breccia (P9), from West Bandung Regency, West Java, had mineral reserves that varied in each soil layer, ranging from 4-14\%, very low to moderate. The upper horizon had higher mineral reserves than the lower horizon, but, overall, this pedon would still need external nutritional input if it was to be used for agricultural cultivation.

Most of the samples were taken from old volcanic soil forms, so that the soil was well developed, as reflected in the texture analysis (Table 4), which revealed the dominance of a clay texture. In general, Ultisols are generally considered to be poor in mineral (nutrient) reserves; however, the findings of this study suggest that some of the Ultisols in the study area have relatively useful mineral reserves (P8, P9, P11, and $\mathrm{P} 15)$, while others have relatively high mineral reserves (P10). These may be the result of differences in the degree of weathering at the different sample locations. The rate of chemical and mechanical mineral weathering is closely related to local rainfall conditions, soil cover, and soil management practices.

\section{Conclusion}

This study found that the color of basaltic andesites (and their associations) varied hue from $2.5 \mathrm{YR}$ to $10 \mathrm{YR}$, with value of 3-5 and chroma of 2-8, and that they had very fine (clay) texture. Ultisols were derived from basaltic andesites in five pedons, which were observed to have poor soil chemical properties. The sand mineral contents were dominated by opaques, zircon, quartz, weathered minerals, rock fragments, and hypersthene. The mineral reserves varied from very low to very high. The highest amount of mineral reserves was found in the pedon derived from basaltic andesite tuff/lava (P10), which was especially rich in $\mathrm{Mg}$ derived from hypersthene. The results of this study are expected to be used as recommendations for Ultisol management in agricultural areas.

\section{Declaration of Competing Interest}

The authors declare no competing financial or personal interests that may appear and influence the work reported in this paper. 


\section{References}

Allen; Hajek. (1989). Mineral occurrence in soil environment, 199-278.

Andalusia, B., \& Arabia, T. (2016). Karakteristik tanah ordo ultisol di perkebunan kelapa sawit PT. Perkebunan Nusantara I (Persero) Cot Girek Kabupaten Aceh Utara. Jurnal Kawista Agroteknologi, 1(1), 45-49.

Asano, M., Wagai, R., Yamaguchi, N., Takeichi, Y., Maeda, M., Suga, H., \& Takahashi, Y. (2018). In Search of a Binding Agent: Nano-Scale Evidence of Preferential Carbon Associations with Poorly-Crystalline Mineral Phases in Physically-Stable, Clay-Sized Aggregates. Soil Systems, 2(2), 32. https://doi.org/10.3390/soilsystems 2020032

Asio, V. B., \& Jahn, R. (2007). Weathering of basaltic rock and clay mineral formation in Leyte, Philippines. Philippine Agricultural Scientist, 90(3), 222-230.

Balai Besar Penelitian dan Pengembangan Sumberdaya Lahan Pertanian. (2019). Peta Tanah Indonesia.

Best, M. G. (1982). Igneous and metamorphic petrology. Igneous and metamorphic petrology. https://doi.org/10.1029/eo064i023p00404

Bowen, N. L. (1922). The reaction principle in petrogenesis. The Journal of Geology, 30(3), 177-198.

BPT. (2009). Petunjuk Teknis Analisis Kimia Tanah, Tanaman, Air dan Pupuk. Balai Penelitian tanah. https://doi.org/10.1007/s13398-014-0173-7.2

Buurman, P. \& J. Dai. 1976. Research on Podzolic soils in Central and North Lampung (Sumatra) and it's bearing on agricultural development. p. 117-149. In Peat and Podzolic Soils and Their Potential for Agriculture in Indonesia. Proceeding ATA 106 midterm seminar, October 1976. Soil Research Institute, Bogor

Buurman, P., \& Subagjo (1980). Soil formation on granodiorites near Pontianak, West Kalimantan. In P. Buurman (Ed.), Red soils in Indonesia (pp. 107-118). (Agricultural Research Reports; No. 889).

Carter, M. R., \& Gregorich, E. G. (2007). Soil Sampling and Methods of Analysis (Second Edition). CRC Press (Vol. 44). CRC Press. https://doi.org/10.1017/s0014479708006546

Chinchilla, M., Mata, R., \& Alvarado, A. (2011). Characterization and classification of Ultisols of LoS Santos, Talamanca, Costa Rica. Agronomía Costarricense, 35(1), 59-81.

Colman, S. M. (1982). Chemical weathering of basalts and andesites: evidence from weathering rinds. US Geological Survey Professional Paper. https://doi.org/10.3133/pp1246

CPHA. (2003). Plant nutrients Potassium. Natural Resources Fact Sheet. California.

Dai, J., P. Soedewo, and P. B. (1980). Soils on acid metamorphic and sedimentary rocks in South East Sulawesi. In Red Soils in Indonesia (hal. 121-140). Bogor, Indonesia: Soil Research Institute.

Eswaran H and Sys. (1970). An evaluation of the free iron in tropical basaltic soils. Pedologie, Vol.20, 62-85. Retrieved from https://www.cabdirect.org/cabdirect/abstract/197119 02755
Fatai, A. A., Shamshuddin, J., Fauziah, C. I., Radziah, O., \& Bohluli, M. (2017). Formation and characteristics of an Ultisol in Peninsular Malaysia utilized for oil palm production. Solid Earth Discussions, (July), 1-21. https://doi.org/10.5194/se-2017-60

Hardjowigeno, S. (1993). Klasifikasi tanah dan pedogenesis. Akademika Pressindo. Jakarta, 320.

Hobart M. King. (2019). Andesite: Igneous Rock. https://geology.com/rocks/andesite.shtml.

Irmak, S., Surucu, A. K., \& Aydogdu, I. H. (2007). Effects of different parent material on the mineral characteristics of soils in the arid region of Turkey. Pakistan Journal of Biological Sciences, 10(4), 528-536. https://doi.org/10.3923/pjbs.2007.528.536

Jackson, T. A. (2012). Igneous rocks and processes: a practical guide, by Robin Gill. Wiley-Blackwell, Chichester, 2010. No. of pages: ix +428 . Price: UKf 34.95. ISBN 978-06320-6377-2 (paperback). Geological Journal. https://doi.org/10.1002/gj.1320

Jenny, H. (1941). Factors of Soil Formation. (McGraw-Hill, Ed.). Michigan, USA: Michigan University. Retrieved from https://books.google.com.tw/books/about/Factors_of _soil_formation.html?id=h-dIAAAAMAAJ\&redir_esc=y

Kolay, A. K. (2007). Soil Genesis, Classification Survey and Evaluation, Volume 2. Atlantic Publishers \& Dist.

Klute, A., \& Page, A. L. (1986). Mathods of soil analysis. Part 1. Physical and mineralogical methods; Part 2. Chemical and microbiological properties (Issue BOOK). American Society of Agronomy, Inc.

Manning, D. A. C. (2010). Mineral sources of potassium for plant nutrition. A review. Agronomy for Sustainable Development. https://doi.org/10.1051/agro/2009023

Myron G, B. (2002). Igneous and metamorphic petrology (2 ed.). Wiley-Blackwell.

Ninuk C. A. (1999). Model Estimasi Katerikatan Mineral Fraksi Pasir Dengan Kadar Hara Tanah dan Tanaman. Institut Pertanian Bogor, Bogor, Indonesia.

Prasetyo, B. H. (2009). Tanah merah dari berbagai bahan induk di Indonesia: Prospek dan strategi pengelolaannya. Jurnal Sumberdaya Lahan, 3(1), 47-60.

Prasetyo, B., \& Suriadikarta, D. (2006). Karakteristik, Potensi, dan Teknologi Pengelolaan Tanah Ultisol untuk Pengembangan Pertanian Lahan Kering di Indonesia. Jurnal Litbang Pertanian.

Prasetyo, Bambang Hendro, Subardja, D., \& Kaslan, B. (2005). Ultisols Bahan Volkan Andesitik: Diferensiasi Potensi Kesuburan dan Pengelolaannya. Jurnal Tanah dan Iklim.

Pusat Penelitian Tanah dan Agroklimat. (2000). Atlas Peta Tanah Indonesia. Bogor, Indonesia.

Schwertmann, U., \& Taylor, R. M. (1989). Chapter 8. Iron Oxides. Minerals in Soil Environments. https://doi.org/10.2136/sssabookser1.2ed.c8

Skinner.B.J. (1984). Sumberdaya Bumi (terjemahan). Yogyakarta, Indonesia: Gadjah Mada University Press.

Soil Survey Staff. (2014a). Kellogg Soil Survey Laboratory Methods Manual. Soil Survey Investigations Report No. 42, Version 5.0. Kellogg Soil Survey Laboratory Methods Manual. 
Soil Survey Staff. (2014b). Kunci Taksonomi Tanah. Edisi Ketiga, 2015. Balai Besar Penelitian dan Pengembangan Sumberdaya Lahan Pertanian.

Stanley W. Buol, Randal J. Southard, Robert C. Graham, P. A. M. (2013). Soil Genesis and Classification 6th Edition. Willey-Blackwell.

Subardja, Djadja S., Ritung, Sofyan., Anda, Markus., Sukarman, Suryani, Erna, dan Subandiono, R. E. (2016). Klasifikasi Tanah Nasional.

Suhardjo, H. \& B. H. P. (1989). Sifat-sifat fisiko-kimia dan penyebaran Tanah Kandiudults di Provinsi Riau. Jurnal Penelitian Pertanian. Universitas Islam Sumatera Utara, 17, 93-102.

Suharta, N. \& B. H. P. (1986). Karakterisasi tanah-tanah berkembang dari batuan granit di Kalimantan Barat. Pemberitaan Penelitian Tanah dan Pupuk, 6, 51-60.

Sulaeman, Y. \& B.H. Prasetyo. (2001). Peranan sifat kimia pada Inceptisols dan Ultisols untuk mendukung pengembangan tanaman pangan di Kalimantan Timur: Implikasinya terhadap pengelolaan Iahan. Jurnal Tanah dan Iklim dan Air, 2, 57-68.
Szymanski, W., \& Szkaradek, M. (2018). Andesite weathering and soil formation in a moderately humid climate: $A$ case study from the Western Carpathians (southern Poland). Carpathian Journal of Earth and Environmental Sciences. https://doi.org/10.26471/cjees/2018/013/010

Tabor, D. (1954). Mohs's hardness scale - A physical interpretation. Proceedings of the Physical Society. Section $\quad B$. https://doi.org/10.1088/0370$1301 / 67 / 3 / 310$

Widiatmaka, Ambarwulan, W., Setiawan, Y., \& Walter, C. (2016). Assessing the suitability and availability of land for agriculture in tuban regency, East Java, Indonesia. Applied and Environmental Soil Science, 2016. https://doi.org/10.1155/2016/7302148

Winter, J. D. (2013). Principles of Igneous and Metamorphic Petrology (2nd edition) (second). Pearson.

Wirjodihardjo \& M. Wisaksono. (1953). Ilmu Tubuh Tanah (II). Jakarta, Indonesia: Noordhoff kolff. 